\title{
Energy-saving Strategy of Building Skins System in Hot-summer and Cold-winter Zone
}

\author{
Chongjie Wang*, Hong Zhang, Bing Tang and Jie Li \\ School of Architecture and Urban Planning, Shandong Jianzhu University, Jinan, China \\ ${ }^{*}$ Corresponding author
}

\begin{abstract}
It is difficult to design the building skins because there are several intractable contradictions among different strategies. For instance, sun-shading design can reduce the impact of solar radiation in summer, but it can also impair the natural lighting, ventilation and winter sunlight absorption. Namely, the building skins, as the climate boundary of a building, can affect the heating, cooling, ventilation and lighting of the building, which can impact the indoor comfort and energy consumption directly. To maximize indoor comfort with minimum building energy consumption, this paper investigated and reviewed design theory and methodology of climate-adaptive building skins. As a result, the design discipline was proposed that building skins should filter out unfavorable climate factors but absorb favorable climate factors up to the hilt. The following climate-adaptive design strategies are recommended in hot-summer and cold-winter zone of China: (1) sunshade integrated with building skin system, (2) solar energy utilization integrated with building skin system, (3) ventilation integrated with skin system.
\end{abstract}

Keywords-building skins; climate-adaptive; energy-saving strategy; energy consumption

\section{INTRODUCTION}

The whole society, especially the architect, has the responsibility to take measures to reduce building energy consumption for the sustainable development and energy conservation. The building skins, as the climate boundary of a building, has effects on the energy exchange between indoor and outdoor, and determines the energy consumption of heating, cooling, ventilation, and lighting. There are rich solar heat resources in Chinese hot-summer and cold-winter region, which lies in low latitude. The air humidity is relatively high due to many lakes. In summer, cool wind from the Pacific Ocean cannot reach here for the resist of Nan-ling and southeastern hills, so there is no wind. In addition, the heat and high humidity are insufferable. In winter, cold wave from Siberia are hold up by Nan-ling and Southeast hills, so the cold and high humidity cannot leave, which are insufferable, too. ${ }^{[1,2]}$ For many years it was commonly assumed that the contradictions between building shade and lighting, shade and ventilation, summer shade and winter heating, solar energy waste and building high energy consumption are irreconcilable though many measures were tried. However, with the development of science and technology, the variable and diversified designs of building skin provide with new solutions for this problem.

At present, there are few studies on climate-adapted building skins in China. Zhao explored the use of shading technology, compared different shading types, and proposed evaluation based on economy and aesthetics; Hong liang Chu et al. compared the effects of different shading types on energy consumption; Yi bin Li optimized the shading design in hot summer and cold winter areas. In these researches and studies, the effects of summer shading on indoor lighting and energy consumption in winter were not considered, and there was a lack of consideration of the climate adaptability of building skins design strategies, and failed to propose appropriate design principles for different climates. Bao feng $\mathrm{Li}$, in his doctoral dissertation, concluded that the building skins design in the hot-summer and cold-winter areas neglected the climate-adapted through a large number of surveys, investigations, interviews, and experimental comparison tests. Then he proposed a changeable design strategy adapted to the climate building skins in the hot-summer and cold-winter areas. Yan li Liu summarized the existing problems and integrated design methods of solar energy utilization technology, and she discussed the integration design of solar energy and building skin, and the integration of shading elements. Yong ming Chen, taking technical suitability and climate adaptability into account, studied the integration of external shading and buildings in hot summer and warm winter regions. Ting Ren took Guangzhou as an example to study the integrated design of the shading heat-dissipating building photovoltaics in hot and humid areas, and proposed that the balance of solar integrated building design in the region is mainly to meet the requirements of cooling and photovoltaic power generation at the same time. Through the above review, this article summarizes the principles of "filtering" and "absorbing” building skins design, and proposes 3 different forms of design strategies. Methods will be put forward based on the principle that filtering out adverse climatic factors while absorbing favorable climate resources.

\section{Climate-Adaptive Design Principles of the SKIN SYSTEM}

\section{A. Filtering Out Adverse Climate Factors Fully}

The skin is not a simple superposition of a series of envelopes, each with a single function, but an integrated system, each with multi-function, with the development of complicated and systematic design technologies. It allows the building skin to act as a filter, which can adjust itself to enhance, weaken, induce or reject climate resources according to the indoor performance. It is not passively but actively that the skin 
prevents unfavorable climate factors outside, such as rain, heat, and light. In summer, heating is shut out and light are shaded. In winter, cold air and wind cannot infiltrate into the room. As a result, the shapes and appearances of the skin change all the time and show us different characteristics at different time.

\section{B. Absorbing Beneficial Climate Resources Fully}

Hot-summer and cold-winter region is rich in solar and the air is humid. So, the skin is expected to make full use of the solar energy and humid air. With the development of solar energy utilization technology, the skins should be design with solar devices to absorb solar radiation. It prevents the radiation outside and store electricity or hot water for the building. There is no doubt that integration design of solar energy and building is an excellent measure to save energy and reduce emission. In addition, humid air is in favor of the growth of plants and plants can take advantage of the humidity. So, it is great to plant trees or grass around the building and even on the building skin. Plants flourish and beautify the building and even the city, which improve the micro-climate of the building and even the city. Furthermore, plants make the building performance comfortable by absorbing overheat solar radiation and water from the air.

The heat of the sun radiation is dominant in many climate factors affecting the construction of the indoor environment. [3] There are two ways to regulate solar radiation. One is protecting against sunshine, the other is making full use of sunshine, namely, shading design and integration solar energy and building. The wind is the secondary factor in relation to indoor thermal comfort in the region. [3] There are also two ways to regulate the wind. One is letting the wind in, the other is shut the wind out, namely, designing the vents in the appropriate position and opening or closing the vents timely. In response to the weather hot with humid and cold with humid, three suggests were put forward: 1) integration shading design and skin system, 2) integration solar energy utilization and skin system, and 3) integration ventilation design and skin system.

\section{Climate-Adaptive Strategies OF BUiLding SKIN SYSTEMS}

\section{A. Integrated Design of Shading and Skin System}

Sunshade is a local technique in the southern China. The pursuit of arts and technologies is getting higher and higher, the combination of sun shading components and the building envelope is clever. The shading components are multifunctional, symbolic, and systematized, which implies the main elements, the concept of design and so on. Some components are changeless while others are adjustable. Though all the components are standardized, adjustable components can move or rotate or flip flexibly separately like human sensory organs. They are controlled by sensors and driven by electricity.

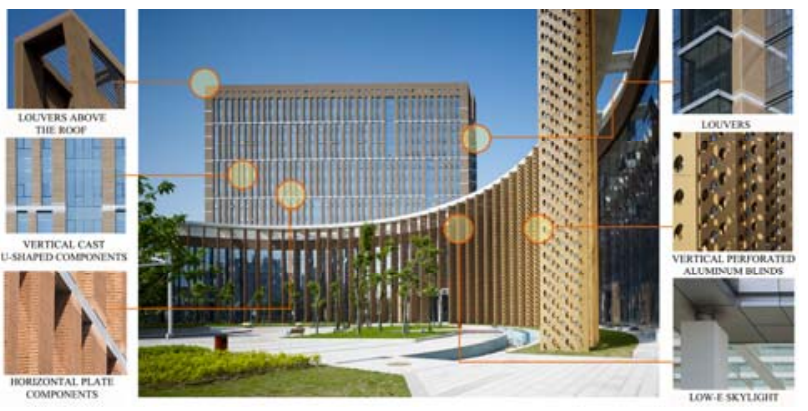

FIGURE I. THE HEADQUARTERS OF CHANGSHA ZHONG-DIAN SOFTWARE

The facades of the Headquarters of Changsha Zhong-jian Software combined shading with function and sculpt as figure 1 showed. The frame above the roof and shutter is not only the architectural design elements, but also the shading component, which avoids the flat roof to be overheating. Moreover, the roof provides a comfortable activity space for people. The horizontal plate, vertical cast U-shaped components, vertical cast-in-place louvers and vertical perforated aluminum blinds altogether consist of the skin. Not only is the shading effect excellent, but the modeling is elegant.

\section{B. Integrated Design of Solar Energy and Skin System}

Nowadays, renewable energy source especially solar energy is encouraged to be used in building field by the government in the context of environment and energy crisis. [4] Most area of Hot-summer and cold-winter lies in area III of solar energy resource and solar energy utility is expected to be combined with building. It is possible to design southern facade or balcony, roof grille, window hole with solar photo-voltaic or photo-thermal components. Photo-voltaic cells can be even made as louvers if larger components are considered incongruous. With the development of solar photo-voltaic technology, solar photoelectric films emerged, which are flexible to combine with special surface. ${ }^{[5]}$

The photo-voltaic curtain wall of Changsha Zhong-jian Building is a typical case of photo-voltaic louver. The louvers are installed between two pieces of glass. The outer glass is ultra-white glass and the inner layer is a heat-reflective glass, which bring about most solar radiation shining into the cavity but least solar radiation into the room. The battery plate is spaced at 20 millimeters and 45 degrees as figure 2 showed. According to the test, the shading coefficient reaches more than $65 \%$ while a great deal of solar radiation is absorbed. [6] The curtain looks the same as the curtain without louver cells, and the daylighting feels better than the room with common curtain. 


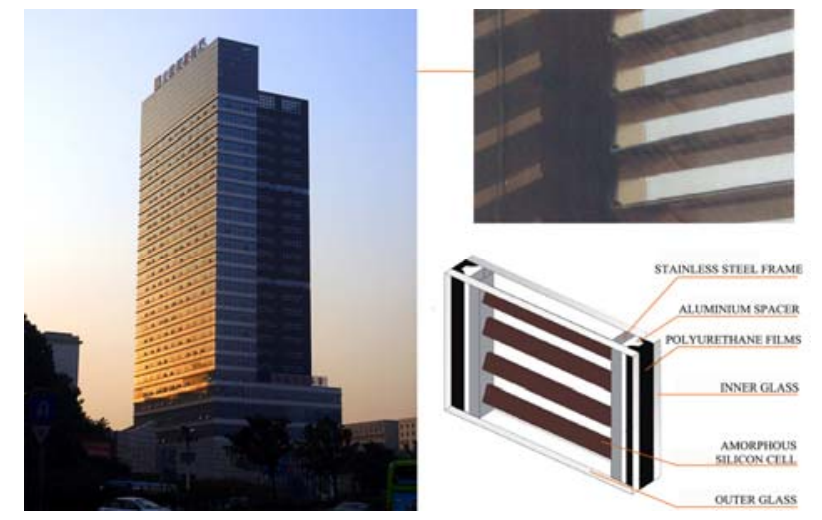

FIGURE II. THE PHOTO-VOLTAIC CURTAIN WALL OF CHANGSHA ZHONG-JIAN BUILDING

\section{Integrated Design of Ventilation and Skin System}

The climate characteristics of hot-humid and cold-humid require the building skins shading the sunshine in summer and insulation the heat in winter. Li, B.F. demonstrated that integration design of ventilation and skin system was very suitable for hot-summer and cold-winter zone. [1,2] By properly controlling the opening and closing of inlet and outlet, indoor natural ventilation is strengthened because of chimney effect. [7] There are three main modes correspond to summer, winter, and transition season as showed in figure 3.

In spring and autumn, outdoor fresh air flows into the cavity from the bottom inlet. And the fresh air rises into the room from the upper vent after heated by solar radiation. So the room is full of fresh air. In winter, indoor air flows into the cavity from the bottom inlet, and then rises back into the indoor or circulating HVAC system cycle after heated by solar radiation. In summer, open the inlet and outlet outside at the same time, so air in the cavity is heated and rise outside. It not only prevents the heat conduction to the room, but also takes away the heat from the room continuously. If blinds shade facilities are installed in the cavity, less solar radiation will shine into the room. The integration design of ventilation and skin system reduces heating and cooling energy consumption.

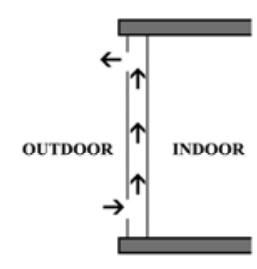

SUMMER

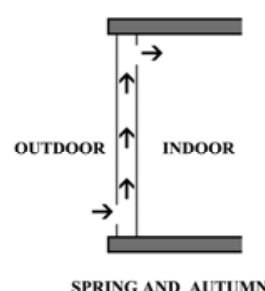

SPRING AND AUTUMN

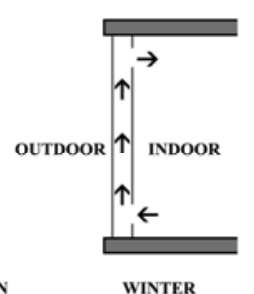

WINTER
FIGURE III. THREE MAIN MODES OF INTEGRATION DESIGN OF VENTILATION AND SKIN SYSTEM

\section{SUMMARY}

The climate-adaptive design of building skin system in hot-summer and cold-winter area improves the indoor comfort performance and saves energy. Redundant light and heat can be filtered out and absorbed effectively in summer while indoor heat can be shut inside and solar radiation can shine into the room, so energy consumption is decreased. To some extent, the contradictions between building sun shading and lighting, sun shading and ventilation, summer sun shading and winter heating, solar energy waste and building energy consumption are reconciled in this way. The building is more comfortable with less energy consumption.

\section{ACKNOWLEDGEMENT}

This research was financially supported by the National Science Foundation of China of Science Fund for youth: Study on the Quantitative Control of the Design Parameters and the Coordination Mechanism of the Key Parameters in Near Zero Energy Residential Buildings in the Cold Area (NSFC Grant No. 60173046).

\section{REFERENCES}

[1] B.F. Li, Analysis of types of "double-layer” curtain wall and prospects of their application, Architectural Journal. 11 (2011), 28-31.

[2] B.F. Li, The Research on Climate-active Design Strategy of Building Skin in Hot-summer and Cold-winter Zone. Ph.D. Thesis, Tsinghua University, Beijing, 2004.

[3] X.D. Lin, Green Building, second ed., China Architecture \& Building Press, Beijing, 2011.

[4] B. Qi, B.R. Lin, and W.M. Zhuang, The Design Strategy of Ecology-oriented and Environmentally Friendly Architecture Integrated Skin, first ed., China Architecture \& Building Press, Beijing, 2014.

[5] S.Y. He, W.J. Chu, S.S. Li, and Y.J. Cai, Technical study and application practice at solar Photo-voltaic glass, Architectural Journal. 2 (2009),102-103.

[6] X.F. Gao, Z. Sun and Z. H. Tu, The sunshade demonstration project of Ministry of Housing and Urban-Rural Development of the People's Republic of China, Construction Science and Technology. 15 (2012), 54-56.

[7] Z.H. Tu, Y.H. Yuan and Y. Luo, Application and discussion of sun shading technology in construction engineering, Construction Science and Technology. 1 (2015), 59-61. 